\title{
Генеалогия одной дискуссии в российской историографии
}

\author{
Владимир В. Андреев \\ Санкт-петербургский государственный экономический университет \\ v.v.andreev@gmail.com
}

Рецензия на книгу: Соколов С. В. Концепция происхождения «Варяжской Руси» в отечественной историографии XVIII-XIX вв. в контексте европейских идей раннего нового времени. Екатеринбург: Банк культурной информации, 2015. 316 с.

C середины XVIII века сочинения, посвящённые вопросам древнерусской истории, становятся заметным явлением как в российской, так и зарубежной научной литературе и публицистике. Действительно, вопрос, вошедший в историографию под названием «варяжского», «варяго-русского» и «норманского» до сих пор является одним из наиболее дискутируемым в русской исторической науке.

В конце 2015 г. вышла монография С.В. Соколова, призванная пролить свет на концепции происхождения руси в исторической литературе XVI-XIX вв. В сочинении рассматриваются идеи русской историографии XVIII-XIX вв. относительно «варягов и руси» в контексте европейских исторических и философских концепций Нового времени, что является новшеством для российской исторической науки.

Тема настоящей монографии - «Варяжская Русь». По справедливому мнению автора этот термин «не вполне корректен» (с. 4), хотя здесь лучше сказать «некорректен». Этот термин использовался в сочетании «варяги - русь» и происходит от знаменитой фразы из ПВЛ, помещённой под 6370 (862) г.: «Те варяги назывались русь, как другие назывались шведы, а иные норвежцы и англы... И от тех варягов прозвалась русская земля, новгородцы же и до нынешних времён от варяжского рода, а прежде были славяне» (перевод на современный язык). Необходимо заметить, что термин «Варяжская Русь» введён в научный оборот в последние годы, кажется, В.В. Фоминым.

Вся полемика между «норманистами» и «антинорманистами» во многом имела политический характер, где «антинорманисты» были обижены в своих патриотических чувствах. При этом подавляющее большинство «норманистов» профессиональные историки (Г.З. Байер, Г.Ф. Миллер, А.Л. Шлёцер, С.М. Соловьёв, B.О. Ключевский и т.д.), в то время как «антинорманистами» были историкилюбители или историки второго ряда (М.В. Ломоносов, В.К. Тредиаковский, С.А. Гедеонов, И.Е. Забелин).

C точки зрения структуры монография представляет собой логически завершённое сочинение, в первой главе которого рассматривается источниковая база исследования, которая делится на историографические и исторические источники. Однако вызывает удивление, что исторические источники идут в главе после историографических, хотя хронологически предшествовали им. С.В. Соколов проследил эволюцию взглядов историков на «варяжский вопрос» и поместил их во временной и социокультурный контекст. Периодизация, предложенная автором, логична и не вызывает сомнений. 
Важным представляется описание летописных источников, которым выпала «вспомогательная роль в данной работе» (с. 54). Это описание позволяет читателю лучше понять источниковую базу исторических сочинений XVIII-XIX вв.

Желательно было бы подробнее затронуть обстоятельства появления и тезисы работы Г.З. Байера «О варягах» и объяснить, почему В.Н. Татищев включил её в качестве отдельной главы в свою «Историю Российскую», поскольку именно с сочинения Байера берет своё начало «норманская теория» в российской историографии, а не с диссертации Г.Ф. Миллера.

Вторая глава посвящена разбору исторических сочинений XVI-XVII вв. о происхождении народа и имени Русь. Эта глава позволяет читателю представить развитие исторических идей вплоть до XVIII в., отдельного обзора удостоились иностранные труды, что является сильной стороной монографии.

В третьей главе автор сосредоточился на рассмотрении конкретных концепций в историографии XVIII в. Здесь явно продемонстрирована преемственность от сочинений XVI-XVII вв. и освещены основные концепции происхождения руси: скандинавская, роксоланская, финская, сарматская. Отдельной темой можно считать изыскания русских историков XVIII в., которые продолжали искать библейские корни народов (с. 114-122). Здесь Подробного разбора удостоились взгляды В.К. Тредиаковского, старавшегося вывести «российское имя» из самых древних времён. В этой главе основное внимание уделено дискуссии между сторонниками роксоланской и скандинавской (Г.Ф. Миллер, М.В. Ломоносов, Ф.А. Эмин), а также финской и сарматской концепций (В.Н. Татищев, И.Н. Болтин, Екатерина II, И.В. Нехачин).

В заключительной, четвёртой, главе С.В. Соколов рассматривает развитие предшествующих концепций и появление новых. К XIX в. относится создание ещё одной неславянской альтернативы скандинавской концепции происхождения руси - тюрско-хазарской, которая, впрочем, не нашла достаточного отклика в научной среде того времени. Славянофильские идеи о происхождении руси, как справедливо указывает автор, необходимо изучать в контексте их политических воззрений.

Автору монографии удалось дистанцироваться от излишней политизации вопроса, свойственной дискуссиям последнего времени, что, несомненно, является большим успехом. С.В. Соколов показал преемственность исторических взглядов современных «антинорманистов» от историков XVIII в.

В четвёртой главе подробно рассмотрена одна из самых известных в русской исторической науке публичных дискуссий между М.П. Погодиным и Н.И. Костомаровым. Автор проанализировал основные аргументы сторон в контексте достижений науки XIX в.

K сожалению, в монографии остались не разобранными труды крупнейших учёных П.Н. Милюкова и И.Я. Фроянова, чей вклад в изучение «варяжского вопроса» сложно переоценить. Кроме того, вызывает удивление, что автор не использовал в работе (не указал в списке литературы) такие значимые для настоящей темы труды как:

1. Варяго-русский вопрос в историографии. М., 2010.

2. Лебедев Г.С. Эпоха викингов в Северной Европе. Л., 1985.

3. Ловмяньский Х. Русь и норманны. М., 1985.

4. Славяне и скандинавы. М., 1986.

5. Советская историография Киевской Руси. Л., 1978. 
6. Становление и развитие раннеклассовых обществ. Город и государство. Л., 1986.

7. Фроянов И.Я. Мятежный Новгород: Очерки истории государственности, социальной и политической борьбы конца IX-начала XIII столетия. СПб., 1992.

8. Фроянов И.Я., Дворниченко А.Ю. Города-государства Древней Руси. Л., 1988.

Для историографической работы крайне желательно наличие именного указателя, без которого ориентироваться в монографии довольно тяжело. Среди мелких замечаний можно отметить, что аббревиатура ПВЛ не помещается в статьях, монографиях и учебниках в кавычки - «ПВЛ».

С.В. Соколов проделал большую исследовательскую работу, в необходимости которой нет никаких сомнений, поскольку в последние годы вновь возник исторический и политический интерес к «варяжскому вопросу» (сочинения В.В. Фомина, А.Н. Сахарова, А.Г. Кузьмина, Л.П. Грот и др.). Автор убедительно доказывает правоту скандинавской концепции, которая является наиболее научной из представленных в монографии, что при нынешнем уровне политизации вопроса показывает высокий научный уровень работы. 